\title{
FINANCIAL VERSUS MONETARY MERCANTILISM-LONG-RUN VIEW OF LARGE INTERNATIONAL RESERVES HOARDING
}

\author{
Joshua Aizenman \\ Jaewoo Lee \\ Working Paper 12718 \\ http://www.nber.org/papers/w12718
NATIONAL BUREAU OF ECONOMIC RESEARCH
1050 Massachusetts Avenue
Cambridge, MA 02138

December 2006

We appreciate comments by Gian Maria Milesi-Ferretti and Charles Wyplosz, but are solely responsible for all errors and misinterpretations. The views expressed in this Working Paper are those of the author(s) and do not necessarily represent those of the NBER, the IMF or IMF policy.

(C) 2006 by Joshua Aizenman and Jaewoo Lee. All rights reserved. Short sections of text, not to exceed two paragraphs, may be quoted without explicit permission provided that full credit, including $\odot$ notice, is given to the source. 
Financial Versus Monetary Mercantilism-Long-run View of Large International Reserves Hoarding Joshua Aizenman and Jaewoo Lee

NBER Working Paper No. 12718

December 2006, Revised February 2007

JEL No. F15,F31,F43,F51

\begin{abstract}
The sizable hoarding of international reserves by several East Asian countries has been frequently attributed to a modern version of monetary mercantilism -- hoarding international reserves in order to improve competitiveness. From a long-run perspective, manufacturing exporters in East Asia adopted financial mercantilism -- subsidizing the cost of capital -- during decades of high growth. They switched to hoarding large international reserves when growth faltered, making it harder to disentangle the monetary mercantilism from precautionary response to the heritage of past financial mercantilism. Monetary mercantilism also lowers the cost of hoarding, but may be associated with negative externalities leading to competitive hoarding.
\end{abstract}

Joshua Aizenman

Department of Economics ; E2

1156 High St.

University of California

Santa Cruz, CA 95064

and NBER

jaizen@cats.ucsc.edu

Jaewoo Lee

Research Department

International Monetary Fund

Washington DC, 20431

jlee3@imf.org 


\section{OVERVIEW}

The growing stockpiles of international reserves held by emerging markets have prompted a considerable debate. Among the explanations advanced, Dooley, Folkerts-Landau, and Garber (2005) took the perspective of modern mercantilism -- hoarding international reserves as part of a deliberate development strategy, which facilitates growth by maintaining an undervalued real exchange rate. They also opined that international reserves potentially served as a "collateral” for encouraging foreign direct investment. This interpretation takes for granted the advantages of outward oriented growth strategy, viewing hoarding reserves as an integral part of it.

An alternative interpretation for the sizable hoarding of international reserves is the selfinsurance/ precautionary demand, as described in the earlier work of Ben-Bassat and Gottlieb (1992) that viewed international reserves as output stabilizers. International reserves can reduce the probability of an output drop induced by capital flight and/or the depth of the output collapse when the sudden stop materializes. Aizenman and Marion (2003) attributed the large increase in international reserves in Korea and other East Asian countries to the aftermath of financial crises during the 1990s. Similar views have been voiced by the researchers who used more elaborate models [see Lee (2004), Garcia and Soto (2004), Aizenman and Lee (2005), and Jeanne and Ranciere (2005)]. These authors concluded that part of the large increase in reserves is consistent with self insurance motives in the presence of sudden-stop risks. ${ }^{1}$ Rodrik (2005) also pointed out

\footnotetext{
${ }^{1}$ Another self-insurance interpretation deals with precautionary hoarding of international reserves needed to stabilize fiscal expenditure in developing countries in the context of Barro's distortion smoothing (see Aizenman and Marion, 2004). Specifically, a country characterized by volatile output, inelastic demand for fiscal outlays, high tax collection costs and sovereign risk may want to accumulate both international reserves and external debt. External debt allows the country to smooth consumption when output is volatile. International reserves that are beyond the reach of creditors would allow such a country to smooth consumption in the event that adverse shocks trigger a default on foreign debt. Political instability, by taxing the effective return on reserves, can reduce desired current reserve holdings. The tests reported by Aizenman and Marion (2004) are consistent with this interpretation.
} 
that increasing the ratio of international reserves to short terms debt can be achieved by combining reserve accumulation with a reduction in short-term debt exposure. ${ }^{2}$ Aizenman and Lee (2005) evaluated the relative importance of these approaches by augmenting the conventional econometric specifications for international reserves with new variables associated with the mercantilism and self-insurance/precautionary demand approaches. While variables associated with both approaches are statistically significant, the self-insurance variables play a greater economic role in accounting for recent trends.

The purpose of the present paper is to infer the association between mercantilism, economic growth, and hoarding reserves by looking at the development strategies of East Asian countries during recent decades. Taking a long-run perspective is useful because the outward growth orientation of East Asia goes back more than four decades, whereas the sizeable hoarding of international reserves started in the early nineties. The history of the region suggests the prevalence of export promotion by preferential financing, which effectively subsidized investment in targeted sectors. This was achieved in several ways, including direct subsidies funded by state banks; or by means of financial repression where favored sectors enjoyed preferential access to cheaper external borrowing; or via "moral suasion” where private banks were encouraged to provide favorable financing. We refer to this policy as financial mercantilism, and contrast it with monetary mercantilism, a policy that hinges on hoarding international reserves. ${ }^{3}$

\footnotetext{
${ }^{2}$ Hence, Rodrik suggests that emerging markets over-invested in the costly strategy of reserve accumulation and underinvested in capital-account management policies to reduce their shortterm foreign liabilities.
}

${ }^{3}$ Wyplosz (2002) used the expression in a similar context: “...financial mercantilism i.e. the desire to keep domestic savings home in order to finance domestic investment and growth.” Favorable financing [what we dub financial mercantilism] and favorable treatment of successful producers as a means of encouraging exports was part of the classical mercantilism:

"Most of the mercantilist policies were the outgrowth of the relationship between the governments of the nation-states and their mercantile classes... These policies took many forms. 
These two mercantilist approaches differ both in terms of transparency and the economic channels at work. Financial mercantilism is frequently less transparent, and may promote exports in the long run independently of the nature of the monetary regime. In contrast, monetary mercantilism is directly linked to hoarding reserves, thereby having direct monetary implications, and its efficacy is bounded by the flexibility of price and wage adjustment in response to monetary policy. Yet, both forms of mercantilism are associated with economic costs, and may lead to unintended adverse consequences.

The history of Japan and Korea suggests the (near) absence of monetary mercantilism during the phase of fast growth. Abounding anecdotal evidence, occasionally supported by more detailed analysis, suggests that financial mercantilism had been vigorously applied during the phase of rapid growth. In both countries, the switch to large hoarding of international reserves happened at times of collapsing growth. Thus, if monetary mercantilism played any significant role in these countries, it was adopted in periods of disappointing growth.

Domestically, governments would provide capital to new industries, exempt new industries from guild rules and taxes, establish monopolies over local and colonial markets, and grant titles and pensions to successful producers.”

The Concise Encyclopedia of Economics, 2006, Mercantilism, by L. LaHaye.

"As conventionally pictured, mercantilism was a long chapter of simple coherence in the history of European economic thought and national economic policy, extending from roughly 1500 to 1800. With diverse expositors and practitioners scattered far over space as well as time, it was intended to promote production and commerce of private entrepreneurs who benefited from and contributed to the consolidation, prosperity and power of nation-states, with foreign trade being the most strategic variable.

......The precepts and proposals of mercantilism were the economic component of state-building, providing much of the rationale and suggesting some of the procedures of national unification, seen especially in England, France and Spain. Men of trade sought the protection and the order essential for expansion of their activity, as well as monopolistic subsidization of their ventures from the crown.”

The New Palgrave: A Dictionary of Economics, 1987, Mercantilism, by William R. Allen. 
We discuss in detail the implications of these regularities. The legacy of financial mercantilism led to deteriorating balance sheets of affected banks. The resultant financial fragility is more sustainable in times of rapid growth, but it may induce banking crises when growth flounders. As the switch to large hoarding of reserves coincides frequently with the collapse of growth, it is difficult to disentangle monetary mercantilism from precautionary hoarding that is intended to mitigate the growing risk of currency crises induced by financial fragility. Moreover, monetary mercantilism and precautionary hoarding may be mutually complementary: the competitiveness benefit may reduce the effective cost of hoarding reserves and induce governments to prefer reserve-hoarding over alternative precautionary means. ${ }^{4}$

Furthermore, monetary mercantilism is associated with negative externalities akin to competitive devaluation. Hoarding international reserves motivated by short-run competitiveness concerns of one country may trigger other countries into adopting a similar policy, to preempt any competitive advantage gained by the first country. These circumstances may lead to competitive hoarding of reserves, which in turn would dissipate any competitiveness gains. We provide a simple framework illustrating the welfare losses associated with competitive hoarding. These losses may provide a novel argument in favor of regional funds, viewed as a mechanism to cope with regional negative externalities.

It is not our intention in this paper to offer a normative statement on the pros and cons of what we call financial and monetary mercantilism. The normative question can be answered only by carefully quantifying all costs and benefits of the two varieties of mercantilism, and then by comparing the welfare of diverse agents who are differently affected by them. Instead, we offer a positive long-run interpretation of the forces behind the phenomenal hoarding of international reserves by several countries.

The rest of the paper is organized as follows. Section 2 discusses the phases of financial and monetary mercantilism for Korea and Japan. Section 3 discusses their economic implications both domestically and internationally, including the logic of competitive hoarding and a case for

\footnotetext{
${ }^{4}$ For the discussion of efficiency of reserves as means of precaution, see Caballero and Panageas (2004), and Lee (2004). Rodrik (2006) offered a similar critique, by calling for simultaneous reduction of reserves and short-term external debt.
} 
regional pooling. Section 4 discusses the near observational equivalence between monetary mercantilism and the precautionary hoarding, and Section 5 concludes.

\section{FinANCIAL VERSUS MONETARY MERCANTILISM OVER THE DECADES: 1970-2005.}

We start with a case study of Japan and Korea during the last 35 years. Figure 1 traces the International reserves/GDP [along the left scale] and the GDP per capita growth rate [along the right scale] in both countries, where the horizontal dotted line corresponds to zero growth rate. We center the time line at the 1997 financial crisis for Korea, and the beginning of the relative stagnation in Japan, around1992. Intriguingly, in both countries international reserves were almost flat at a low level during the years of rapid growth, and "took off" during periods of relatively sluggish growth - from the early 1990s in Japan, from 1998 in Korea. Compared to the average over the decade prior to crisis, the foreign exchange reserves in percent of GDP rose by nearly five-fold after 8-10 years since the crisis.

There is a significant body of evidence that financial mercantilism played an important role during the phases of rapid growth of Japan and Korea [see Amsden (1989), Kim and Leipziger (1993), Noland (2005), Rodrik (1995), Noland and Pack (2003), and Doi and Hoshi (2002)]. Financial mercantilism operated at the background of financial repression and considerable involvement of the government in the allocation of credit. Because financial mercantilism operated under conditions of limited transparency, quantifying the magnitude of these subsides remains a challenge. The better documented experience of Japan's, however, indicates that the order of magnitude of these subsides has been staggering. For example, Doi and Hoshi (2002) reported:

"When the FILP (Fiscal Investment and Loan Program) started in the 1950s, financing the economic recovery was the most important goal for the government. Hence, the FILP heavily targeted the industrial financing through the Japan Development Bank (predecessor of the present Development Bank of Japan) and other government financial institutions.” ... "The Fiscal Investment and Loan Program (FILP) in Japan collects funds through government financial institutions (most notably postal savings) and use the funds to finance public projects undertaken by government-affiliated corporations or to finance government loans to borrowers in targeted areas 
(targeted industries, small firms, mortgage borrowers, etc.). Many countries have government sponsored loan programs. The Japanese program is distinguished in its size. As of the end of fiscal 2000 (March 2001), for example, the outstanding amount of the FILP stood at more than $80 \%$ of GDP. The postal savings, which is the most important source of funds for the FILP, is the world's largest financial institution, accepting 35\% of total household deposits as of the end of fiscal 2000”

The legacy of this strategy is the growing fragility of the banking system, an issue that becomes more transparent when growth flounders, as has been the Japanese experience. ${ }^{5}$ Doi and Hoshi reported in 2002 that "Our estimates suggest as much as 75\% of the FILP loans are bad. The expected losses are likely be $16 \%$ of GDP, or higher.”

Figure 1 suggests that floundering growth may have provided the impetus towards both precautionary hoarding and monetary mercantilism, augmenting or replacing the credit subsidy with hoarding reserves. This switch may be triggered by budgetary/precautionary concerns related to the growing weight of bad loans, or/and as a "last resort" attempt to revitalize declining growth. Moreover, the two motives can reinforce each other. When the financial sector is saddled with non-performing loans, the government would want to make provisions against these loans [see Krueger (2002) for a discussion of prevailing standards for provisions]. The mercantilist benefit of maintaining a competitive exchange rate reinforces the attraction of hoarding reserves as a means of making provisions for financial fragility, compared to other means that do not help to maintain a competitive exchange rate-including structural reforms that strengthen the financial sector.

The two forms of mercantilism differ considerably. Financial mercantilism operates though the direct cost of investment, and may increase investment in enduring ways. In its

\footnotetext{
${ }^{5}$ It is difficult to distentangle the historically cumulated fragility from that which might have been generated by the property boom during the pre-crisis decade. However, suggestive evidence is provided by Iwamoto (2002) who report that the FILP loans averaged 5 percent of GDP since the mid-1950s, buttressing the possibility that a large part of the bad FILP loans originated during the earlier decades.
} 
incarnation as export-oriented growth strategy in East Asia, financial mercantilism can improve long-run economic efficiency when there are strong dynamic externalities in the economy, such as learning by doing and knowledge spillovers. In general, the case for financial mercantilism remains debatable, and may hinge on government ability to pre commit and the nature of the strategic interaction among competitors. ${ }^{6}$ Dynamic externalities have often been postulated in models of economic growth in the name of knowledge accumulation or learning by doing, exemplified by Romer (1990) and the follow up literature. ${ }^{7}$ While we don't argue that the case for export subsidies is watertight and universal, the revealed preferences of policy makers in Japan and Korea indicate their presumption that the gains from such subsides in the early development stages warranted financial mercantilism. Indeed, some observers made the case that, with proper implementation, such policy worked well for these countries. ${ }^{8}$

In contrast, for monetary mercantilism to be potent, prices and wages should adjust in an extremely sluggish manner, and trade rivals should refrain from adopting similar policies. If other countries adopt similar mercantilist policies, they can undermine the exchange rate effect of the mercantilist attempt by the home country and lead to a competitive real depreciation. In addition, the speed of price adjustment determines the time frame over which monetary mercantilism can remain effective. Monetary mercantilism would have sizable effects usually as long as monetary policy has real effects--typically the duration of a business cycle. Little evidence exists that monetary policy can have long-run effects beyond that, and certainly not over the duration of economic growth for a whole generation. Even if monetary mercantilism succeeds in keeping the nominal exchange rate at a desired level, inflationary pressures will erode competitiveness by appreciating the real exchange rate.

\footnotetext{
${ }^{6}$ For example, Leahy and Neary (1999) show conditions under which optimal export subsidy is increasing in the rate of learning with government precommitment but decreasing in it without. See Fundenberg and Tirole (1983) for study of learning by doing in a closed economy, and Spencer and Brender (1983) for a model of international R\&D rivalry and industrial policy.

${ }^{7}$ The often cited "Dutch disease” also postulates a variant of dynamic externality, though applied to the detriment of an economy in which the activity in the sector with dynamic externality declines in response to a favorable external shock, often in commodity exports [Krugman (1987)]. For financial development, Lee (1996) discusses financial underdevelopment trap that hinders the accumulation of information through learning by doing.
} 
Both types of mercantilism come with a cost, too. Financial mercantilism increases financial fragility, and may lead to abuse and overinvestment in inefficient activities. Cumulated over time, the cost may turn into a significant macroeconomic hazard, either culminating in a macroeconomic crisis or calling for a sizable precautionary undertaking ahead of a full-blown crisis. Monetary mercantilism is frequently associated with costly sterilization, which may be outweighed by short-term competitiveness gains if other countries do not follow similar policies. If they do, monetary mercantilism may lead to a competitive hoarding described below, which renders even its short-lived mercantilist benefit ineffectual.

\section{THE HAZARD OF COMPETITIVE HoARding}

Monetary mercantilism is subject to negative externalities, akin to competitive devaluation. Countries that compete in similar third market destinations may end up following a policy of competitive hoarding, which in the symmetric case would not alter their relative competitiveness, but would lead to large hoarding. To exemplify this concern, we focus first on a simple case of two symmetric countries, $\mathrm{H}$ and $\mathrm{F}$, in a one shot game. Both countries start with international reserves at levels $R_{0} ; R_{0}^{*}$, respectively. For notational simplicity, we assume a symmetric initial hoarding, $R_{0}=R_{0}^{*}=1$. The initial international reserve stocks may reflect self insurance/precautionary demand and other, non mercantilist motives. ${ }^{9}$ Hoarding more reserves by $\mathrm{H}$ is assumed to depreciate H's real exchange rate, thereby improving H's short run competitiveness vis-à-vis country F. We model this situation assuming that H's net export is imperfect substitute of the exports of $\mathrm{F}$, and depends positively on the relative hoarding of international reserves of the two countries, $N E=1+g\left[\left(R-R_{0}\right) /\left(R^{*}-R_{0}^{*}\right)\right]^{\alpha} ; \quad \alpha \geq 0$, where R and $\mathrm{R}^{*}$ are the actual international reserve levels of country $\mathrm{H}$ and $\mathrm{F}$, respectively. Hoarding international reserves comes at a quadratic cost, reflecting costly sterilization and other indirect costs. The policy maker in country H maximizes the following reduced form "utility":

\footnotetext{
${ }^{8}$ See World Bank (1993).

${ }^{9}$ Alternatively, these levels can be viewed as the optimal levels of reserves, which have been approached from a variety of viewpoints in aforementioned papers.
} 
(1) $1+g\left[\frac{R-R_{0}}{R^{*}-R_{0}^{*}}\right]^{\alpha}-b\left(R-R_{0}\right)^{2}$.

The parameters $g$ and $\alpha$ reflect net export's responsiveness to hoarding international reserves, and $b$ reflects the costs of sterilization. A similar situation confronts country F. The reaction functions in a symmetric world are:

$$
\left\{\begin{array}{c}
\frac{\alpha}{R-R_{0}}\left[\frac{R-R_{0}}{R^{*}-R_{0}^{*}}\right]^{\alpha}=\frac{R-R_{0}}{\chi} \quad H \text { 's reaction function } \\
\frac{\alpha}{R^{*}-R_{0}^{*}}\left[\frac{R^{*}-R_{0}^{*}}{R-R_{0}}\right]^{\alpha}=\frac{R^{*}-R_{0}^{*}}{\chi} \quad F \text { 's reaction function }
\end{array} ;\right.
$$

where $\chi=0.5 \mathrm{~g} / \mathrm{b}$, reflecting the export expansion / cost of sterilization ratio.

In a symmetric Nash equilibrium, where $R_{0}=R_{0}^{*}=1$, the non-cooperative outcome is:

$$
\text { (3) } \quad R=R^{*}=1+\sqrt{\alpha \chi} \text {. }
$$

In contrast, the cooperative equilibrium yields $R=R^{*}=1$. Figure 2a plots the reaction functions, where the symmetric Nash equilibrium is at point $S$, whereas the cooperative outcome is at point O. Curve Wo (double lines) plots H’s indifference map - the configuration of R and $\mathrm{R}^{*}$ where H's utility equals the cooperative outcome. Points below (above) this curve are associated with utility above (below) the cooperative outcome. These circumstances may lead to competitive hoarding of reserves, which in turn would dissipate any competitiveness gains, reducing utility by $0.5 \mathrm{~g} \alpha$. Greater substitutability between the exports of two countries would magnify the negative externality associated with hoarding international reserves, and lower sterilization costs would increase the "excess reserves" associated with competitive hoarding. These conditions are more likely to be met in countries exporting manufacturing goods, subject to financial repression. Figure $2 \mathrm{~b}$ corresponds to asymmetric case, where $\chi>\chi^{*}$, as would be the case if the cost of sterilization is lower in country $\mathrm{H}$. Lower sterilization costs shifts curve $\mathrm{HH}$ rightwards, and the indifference map Wo upwards, increasing the aggressiveness of H's hoarding. Low enough cost of sterilization [or for high enough impact of the real exchange rate 
on exports] implies that H would win the "hoarding war" -- H's non cooperative outcome is superior to the cooperative one, akin to the "Beggar-thy-neighbor" outcome of asymmetric tariff wars [see Syropoulos ( 2002) for further discussion of asymmetric tariff wars].

Recent empirical research, while still preliminary, has provided evidence consistent with our discussion. A prediction of the mercantilist motive is that countries exporting to the same third market, competing for market shares there, may engage in competitive hoarding. This in turn would imply “Keep with the Joneses” pattern of hoarding international reserves, in line with the finding of Cheung and Qian (2006). They found evidence of inter-dependence of holdings of international reserves in East Asia, and report that their finding is robust to the presence of standard macro determinants, a few controls, and a few alternative specifications of the “Joneses” variable. For ten East Asian countries, they found that a dollar increase in international reserves by one country has been associated with an increase of about .6 dollar by the other nine “peer countries.”

\section{A. A "Mercantilist" Case for Pooling Reserves in East Asia}

An unintended consequence of competitive hoarding is excessive reserves, where the competitive gains are dissipated. The inefficiency associated with competitive hoarding may provide the impetus for the formation of institutions that would allow coordination. For example, an “Asian International Reserve Fund” may provide an umbrella institution that would commit the countries to refrain from competitive hoarding. ${ }^{10}$ The greater importance of manufacturing in East Asia relative to Latin America, and the deeper financial repression in some East Asian

\footnotetext{
10 This is an example of the usefulness of institutions in dealing with competitive externalities. Melitz (1996) points out that these concerns in the context of the EMU project:

"Concern over competitive devaluations repeatedly comes to the surface in the European Union (EU). Examples arose following the exchange rate crisis of 1992, when the lira, the peseta, and the British pound depreciated greatly and brought some competitive advantages to the depreciating countries. There is also much current discussion of the importance of avoiding competitive devaluations in the initial phase of EMU when there will be both "ins" and "outs." One of the benefits of EMU that its proponents often have in mind is a certain degree of cooperation in the formation of policy."
} 
countries suggests that the case for an Asian fund is stronger than that for a similar regional fund among Latin American countries. ${ }^{11}$

While financial mercantilism does not necessarily impose a negative externality on trading partners (Section 3.2), monetary mercantilism impacting the real exchange rate does and can even lead to a Pareto-inferior equilibrium among monetary mercantilists themselves. The observational near-equivalence between monetary mercantilism and precautionary hoarding (to be discussed in Section 4) makes it difficult to infer the extent of competitive hoarding driven by monetary mercantilism. Regional pooling arrangement can alleviate the pressure of competitive hoarding and enable countries to focus better on precautionary hoarding.

This rationale for regional pooling is independent of the risk-sharing argument, which in fact militates against the regional pooling. If the risks facing countries in the region are more positively correlated among themselves than with those facing countries outside the region, risk sharing outside the region will dominate the risk sharing that can be attained within a region. And there are ample evidence for strong regional correlation of risks. Be it due to trade links or to pure sentiments, financial contagion has been much stronger among countries in the same region. Overall macroeconomic risks have also been found to provide a much greater scope of risk sharing among countries beyond than inside a regional boundary [Imbs and Mauro (2006)].

Once monetary mercantilism is out of the way, the desirable magnitude of precautionary hoarding may decline. Pooling reserves would also provide a side benefit of reducing the scope of unwarranted contagion, potentially reducing the optimal self insurance of countries in a region with significant overlap of the trade vector across countries. The future course of financial mercantilism will be partly determined by the opportunity for dynamic externality. Once the expectable dynamic efficiency gain falls below the cost of static distortion, the efficiencyrationale for financial mercantilism will lose validity.

\footnotetext{
11 The presumption is that the real exchange rate has greater consequences on the competitiveness of manufacturing exporters than on countries specializing in exporting commodities and raw materials.
} 


\section{B. Do Financial Mercantilists Beggar Their Neighbors?}

Financial mercantilism differs from monetary mercantilism in the extent of negative externalities for trading partners. What we call financial mercantilism, outward-oriented growth strategy by means of financial support, can in principle proceed with no beggar-thy-neighbor trade externality. Financial mercantilism promotes the export sector, which results in the shift of comparative advantage as the dynamic efficiency gains are realized. The benefit of efficiency gains improves the welfare of both home and foreign consumers, and has the potential to compensate for the static efficiency losses that may arise in the subsidy phase.

Static efficiency losses that fall on trading partners are the excessive promotion of exports and the consequent job losses in the importing countries. The resulting costs are difficult to quantify, because sector-level transition-involving job destruction in some sectors and job creation in others - is the other side of the coin to the benefit of international trade. Nevertheless, the suspicion of beggar-thy-neighbor effect runs high when a large current account surplus is realized. Financial mercantilism, however, can proceed with any level of current account balance, namely surplus, zero balance, or even a deficit. Indeed, over the course of rapid growth during the past several decades, Korea and Japan did not always run large current account surpluses [Figure 3].

The negative externality of the two varieties of mercantilism can be compared by considering the relative prices that are targeted by them. Monetary mercantilism purports to alter the relative price between home and foreign exports, and can work only by undermining the competitiveness of foreign exports. Financial mercantilism, on the other hand, purports to alter the relative price of capital, in order to facilitate expansion of the sector with dynamic externalities. Pushed beyond a threshold, the lower cost of capital can also end up having a similar effect on the relative competitiveness of foreign exports as the monetary mercantilism, but it is one possible consequence rather than being the only consequence or the objective.

What about the side effect of financial mercantilism, namely the cost of replenishing the weak balance sheet of the banking and financial sector? This side effect would impose a negative externality on trading partners to the extent that the cost of restructuring or provision is borne by trading partners. In practice, the foreigners' share of the restructuring cost is typically very small, 
and the bulk of the cost is borne by current and future tax payers of the country whose financial sector is restructured.

The following question can arise, considering the gigantic amount of the U.S. government securities held as international reserves [McCauley (2005)]. Don’t foreigners pay for the cost, if the mercantilist country holds a large amount of foreign government securities as its international reserves? The answer to this is negative. Foreign (e.g. the U.S.) government securities were purchased at market prices and represent financial transactions between a lender and a borrower. If the lender liquidates the asset in the market or transfers it to commercial banks to bolster their balance sheets, the transaction involves no transfer from the borrower to the lender, in contrast to the transfer from current and future taxpayers to the financial sector that goes on among domestic agents.

The absence or weakness of negative externality in financial mercantilism-unlike monetary mercantilism — does not imply that financial mercantilism is a highly desirable development strategy which every developing country should consider. The almost certain cost of it, namely the deepening fragility of the financial sector, suggests that it is at best a high-risk strategy, which is worth trying only when the associated return is high enough to compensate for the risk. In the case of Japan and Korea and with the benefit of a hindsight, it appears to have delivered a high return during the take-off period, which may have compensated for the apparently high cost, while saddling the present policy maker with the legacy of financial fragility.

The importance of prudent macroeconomic policies should also be noted. Considering the likely burden on the financial sector over the long haul, fiscal and monetary policies should be run in a such way that minimizes the likely burden on the financial sector. Otherwise, the combination of macroeconomic and structural/mercantilist pressures on the financial sector may easily prevent the realization of dynamic externality that is the benefit of financial mercantilism. 
The sustained prudence of macroeconomic (especially fiscal) policies appears to have been an important contributing factor to the working of financial mercantilism in Japan and Korea. ${ }^{12}$

\section{BANK Fragility: On The ObSERVATIOn EquivalenCe OF Monetary Mercantilism AND SELF INSURANCE}

Circumstances where floundering growth leads to the switch from financial mercantilism to large hoarding of reserves are associated with growing fragility of the banking system. This reflects both the legacy of the past borrowing, as well as the deteriorating balance sheet induced by the deterioration of borrower's growth prospects. The research triggered by Kaminsky and Reinhart (1999) points out that greater financial fragility increases the odds of currency crisis. Hutchison \& Noy (2005) report that “... the onsets of 31\% of banking crises were accompanied by currency turmoil. Furthermore, there is a statistically significant correlation between lagged banking crises and contemporaneous currency crises but not vice versa.” This observation is consistent with the insight of models of financial fragility, exemplified by Chang and Velasco (1999).

In these circumstances, precautionary motives may lead countries to hoard international reserves in order to mitigate the possible transmission of banking crisis to currency crisis. With limited data, such a response may be observationally equivalent to the one predicted by monetary mercantilism. Having good data about international reserves but spotty data on non performing loans, it is hard to disentangle the precautionary hoarding from the monetary mercantilism. ${ }^{13}$

\footnotetext{
${ }^{12}$ See Wyplosz (1996) for the discussion of the post-war French experience with government intervention in credit allocation, which is viewed to have had a limited success. Nor is the French experience viewed to have been characterized by very prudent macroeconomic policies.

${ }^{13}$ Financial fragility in China is the outcome of favorable financing provided to the SOE and to other targeted borrowers. See Lardy (1998) and Bonin (2001) for further discussion of financial fragility in China. The ratio of banks' non performing loans/international reserves in China has been estimated to be in the range of about 20\% (according to the Bank of China) to more than 90\% (see Jim Peterson's report at the International Herald Tribune, 9-11-2006). In Barnett (2004), non-performing loans were estimated to be 23 percent of GDP on average for 2002-03, more than 90 percent of the international reserves in 2002-03. Restructuring of non-performing loans would reduce the ratio from the banks' balance sheet, but would not eliminate the economy-wide burden of them. These numbers indicate a large uncertainty associated with estimating the economy-wide burden of financial weakness, which itself would add to the demand for precautionary hoarding.
} 
Given the sheer size of China and its reserve hoarding, however, other countries in the region may be tempted to engage in competitive hoarding in order to mitigate the competitiveness loss in third markets. These interpretations, the merit of which was discussed in Section 3.1, are consistent with growing regional interest in the formation of Asian fund [for further discussion on regional funds see Eichengreen (2006)].

China's hoarding of reserves picked up sharply after the Asian crisis. Its foreign exchange rate reserves rose from \$ 105 billion at the end of 1996 to \$ 820 billion at the end of 2005 (and to \$ 950 billion in July 2006). In percent of GDP terms, this amounts to a five-fold increase, similar to that of the Japan and Korea after their respective financial crisis. Unlike them, China is accumulating reserves without having gone through a sharp slow-down in economic growth. It can be viewed to be accumulating reserves in anticipation of possible deterioration in the strength of the financial sector. We conjecture that the recent history of Japan and Korea provided evidence encouraging China to adopt a dual strategy of financial mercantilism and rapid hoarding of international reserves [Figure 4]. This dual strategy is reinforced by the speed of the Chinese transition from a sleepy giant to a highly open economy [by now its trade openness is more than three times that of Japan]. Arguably, as much as China is growing even faster than Korea and Japan in their early years and is going through its take-off process in the era of a highly integrated global financial market, China faces much greater downside risk of social and political instability associated with a crisis than the risk that confronted Korea or Japan. This greater downside risk of recession and financial crisis may explain both the Chinese eagerness to push financial mercantilism, and to buffer the downside risk of the growing financial fragility with aggressive reserve hoarding.

The prominence of financial mercantilism is supported by Aizenman and Lee (2005) and by Cheung et al. (2006). As discussed earlier, Aizenman and Lee (2005) find that reserves accumulation is more closely associated with precautionary variables - which relate to financial mercantilism - than with variables that capture monetary mercantilism. Nor do we find evidence that China's reserve accumulation was exceptionally larger than those of other countries until 2003 or so, once the effects of standard determinants (population, GDP/Capita, trade openness, etc.) are taken into account. After a detailed examination of the price level data for a panel of more than 100 countries, Cheung et al. (2006) find that China's currency got substantially undervalued by 2004, in terms of the deviation of the price level from the international trend. 
However, the measured undervaluation still falls within the two standard-deviation band of the international trend, leading the authors to conclude that there is little evidence of statistically significant real undervaluation of China's currency. Considering the difficulty with statistical inference in these issues, these results do not constitute an irrefutable proof that monetary mercantilism is absent in China, but strongly suggest that there is more than monetary mercantilism at work behind the rapid accumulation of reserves in China.

As an interpretation of mercantilist tendencies, financial mercantilism is consistent with the apparently slow development of the financial sector in Japan and Korea, as well as in China. When credit is channeled to export sectors with mercantilist intentions, the overall development of the financial sector is in the primary interest of neither the government nor the market. If any, weak development of the arms-length financial market will leave the savings in the banking system, making it easy for the government to direct credits to targeted sectors. Nor is there an immediate need to improve the credit allocation of the banking system. Financial underdevelopment is not just an unintended outcome of unbalanced development, but also a convenient coincidence which the government and market have no pressing desire to escape.

Moreover, the mercantilist push may lead to "status quo” bias: financial repression would be supported by the key players running the show as long as growth continues. The opposition to financial repression reflects mostly the interests of smaller producers, which tend to be less organized due to the free rider problem, and the inability to identify ex-ante the losers from the missing activities that were not financed due to financial repression. This bias may be an example of the incumbent bias against financial development, espoused by Rajan and Zingales (2003).

\section{CONCLUSION}

International reserves held by three East Asian countries of China, Japan, and Korea have exceeded 2 trillion dollars by the summer of 2006. The sheer amount of their reserves, combined with their relentless increase, has aroused a strong suspicion of mercantilist intervention. This interpretation, however, harbors its share of difficulty. It would have been no small feat to keep the real exchange rate undervalued by monetary means for the span of a decade. Nor has it been easy to produce conclusive evidence of massive and persistent undervaluation in the real exchange rate of China, which is the prime target of the suspicion. 
Drawing on existing studies, we provided a heuristic argument for an alternative understanding of the accumulation of reserves in these countries. If the mercantilist push refers to the growth strategy based on export orientation, Japan and Korea may be viewed to have relied on mercantilist push for much of the years of rapid growth. However, the means of decades-long mercantilist push are better sought in the financial sector-based instruments, rather than the monetary instruments whose real effects are unlikely to stretch over decades. Financial mercantilism carries a cost, in the form of heightening fragility in the financial sector, which needs to be reckoned with at some stage. The reckoning appears to have come through financial crises, of a purely domestic variety for Japan and of an international variety for Korea. Subsequent to that, the precautionary motive provides a strong impetus for reserve accumulation.

Additional stimulus to reserve accumulation could have been provided by the possible competitiveness gain of monetary mercantilism, which reduces the perceived cost of precautionary hoarding of international reserves. Monetary mercantilism, when pursued simultaneously by countries with interdependent trade structure, could result in competitive hoarding. The negative externality can push the reserve hoarding beyond the desired precautionary level. Regional pooling of reserves can be one method to internalize the negative externality of competitive hoarding. 
Figure 1. Japan and Korea: Foreign Exchange Reserves and Economic Growth Left scale: International Reserve/GDP; $\quad$ Right scale: GDP/Capita Growth Rate

Foreign Exchange Reserves in percent of GDP

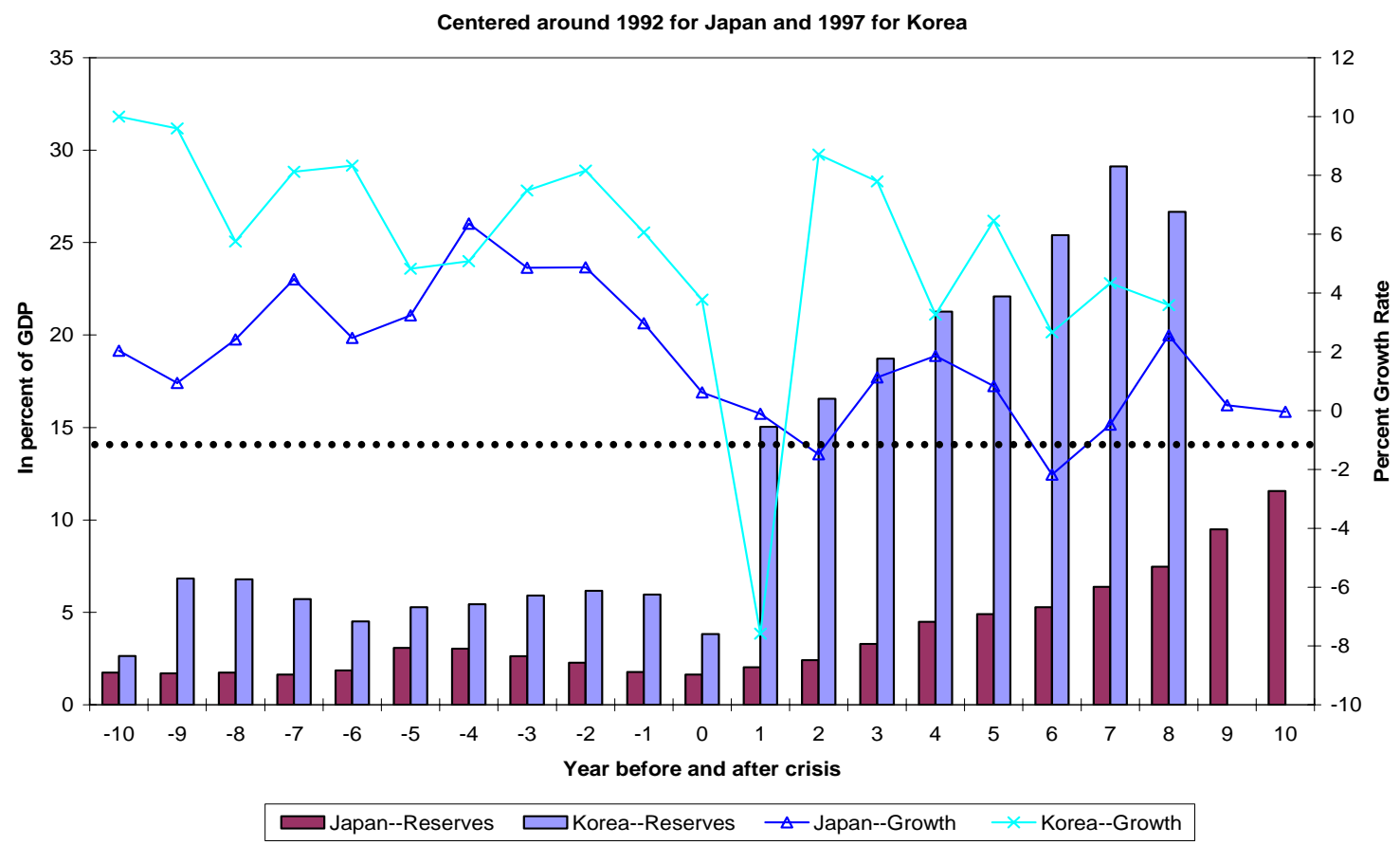

Foreign Exchange Reserves, relative to the average over the pre-crisis decade

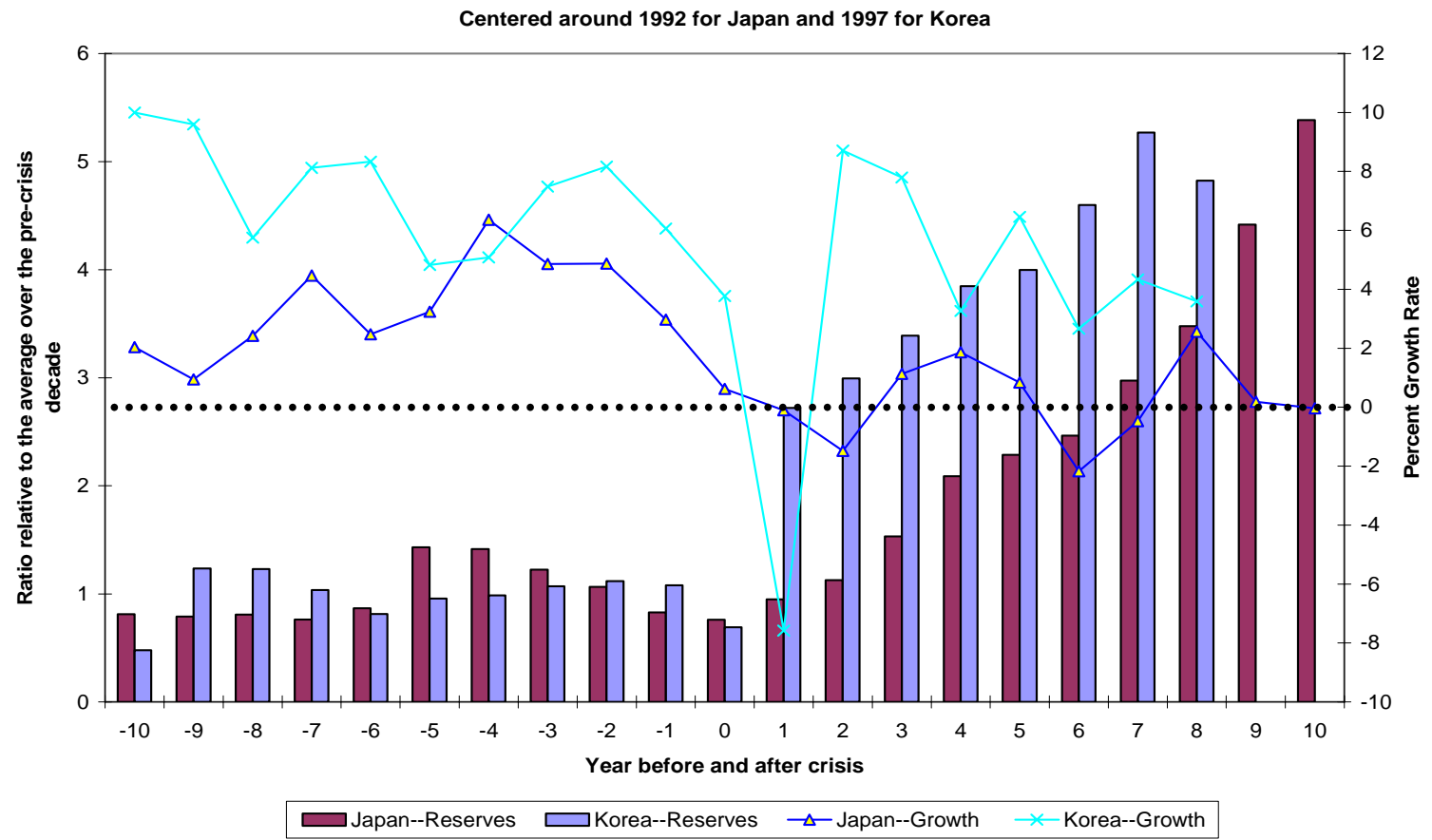

The lower panel presents the reserves-to-GDP ratios divided again by the ten-year averages of the reserves-to-GDP ratios themselves (1987-1996 for Korea and 1982-1991 for Japan). 
Figure 2. Competitive Hoarding

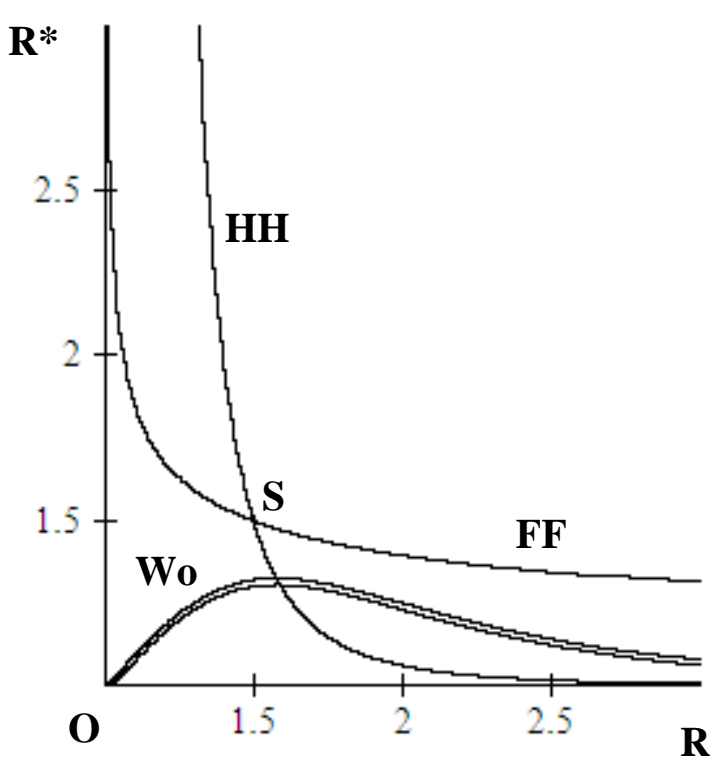

2a: The symmetric case

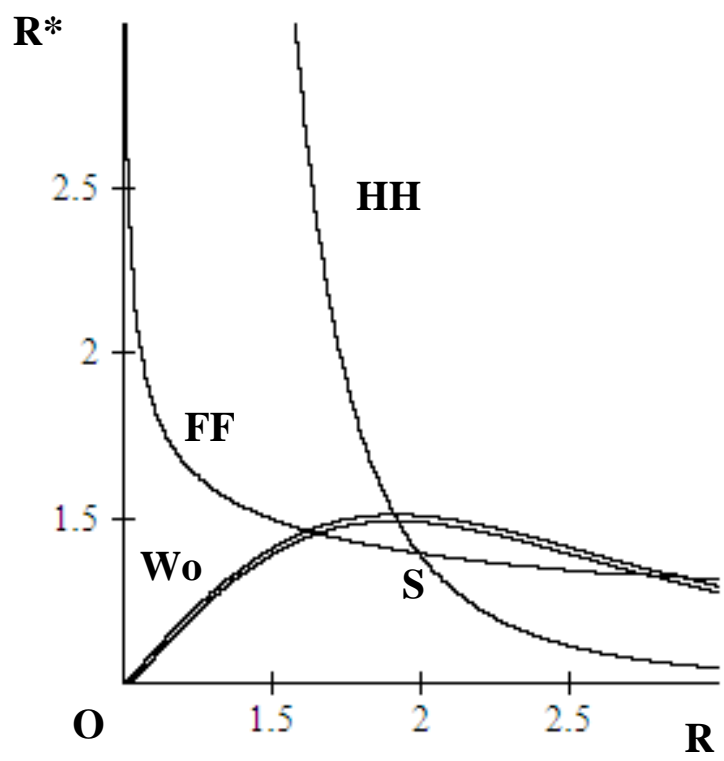

2b: The asymmetric case

$\mathrm{HH}$ and FF are the home and foreign reaction functions, respectively. Point $\mathrm{S}$ is the noncooperative equilibrium. Point O corresponds to the cooperative outcome. Curve Wo is H's indifference map -- $\mathrm{H}$ is indifferent between the cooperative outcome and the $\left(\mathrm{R}, \mathrm{R}^{*}\right)$ forming curve Wo.

The left panel corresponds to the reaction functions in a symmetric world, where $g=g^{*}=1$; $\chi=\chi^{*}=0.5 ; \alpha=0.5$. The right panel corresponds to the asymmetric case, where $g=g^{*}=1$; $\chi=1.25, \chi^{*}=0.5 ; \alpha=0.5$. 
Figure 3. History of Current Account Balances in East Asia

Current Account Balances

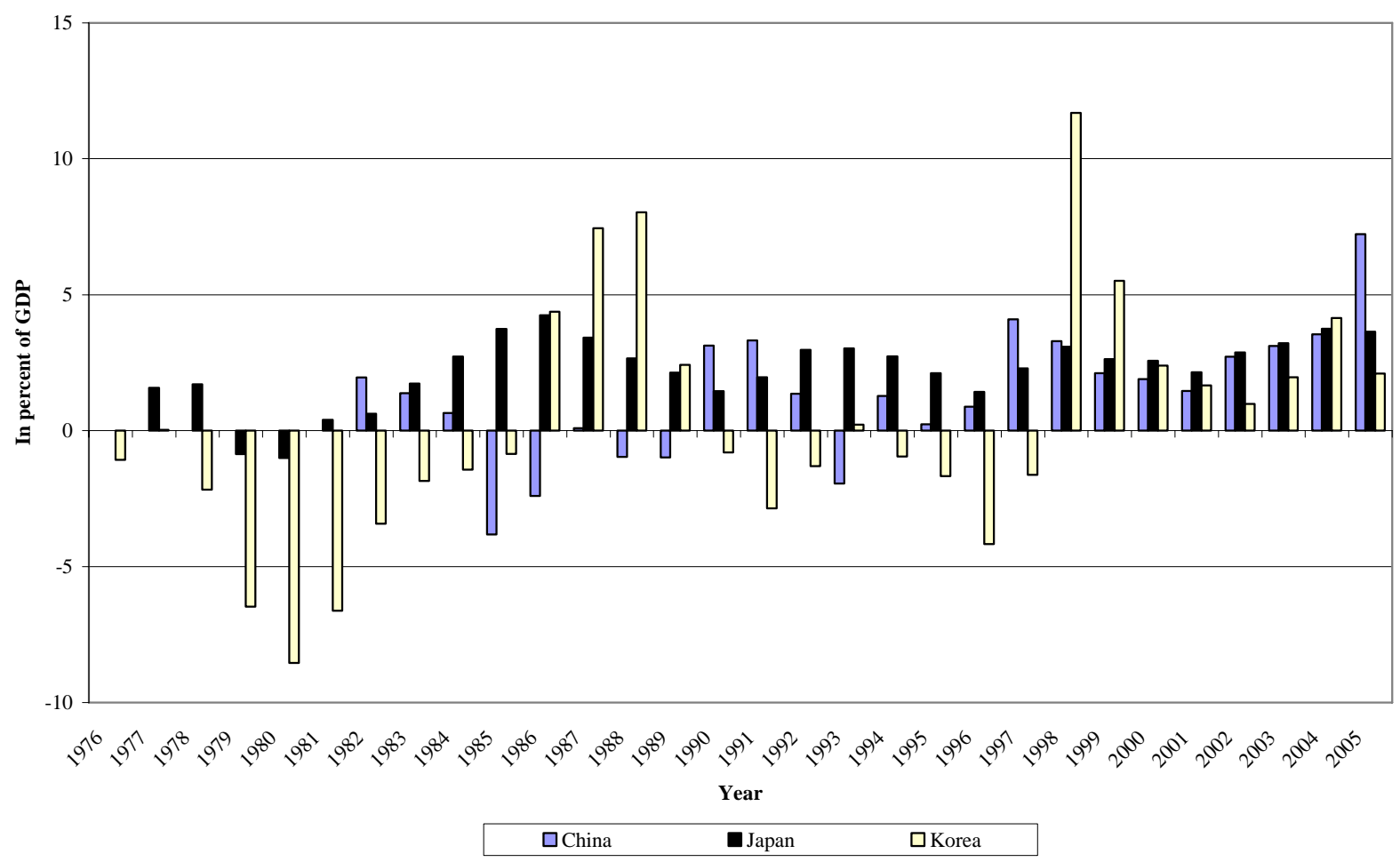


Figure 4. China: Foreign Exchange Reserves and Economic Growth

Left scale: International Reserve/GDP; $\quad$ Right scale: GDP/Capita growth rate

China: Foreign Exchange Reserves

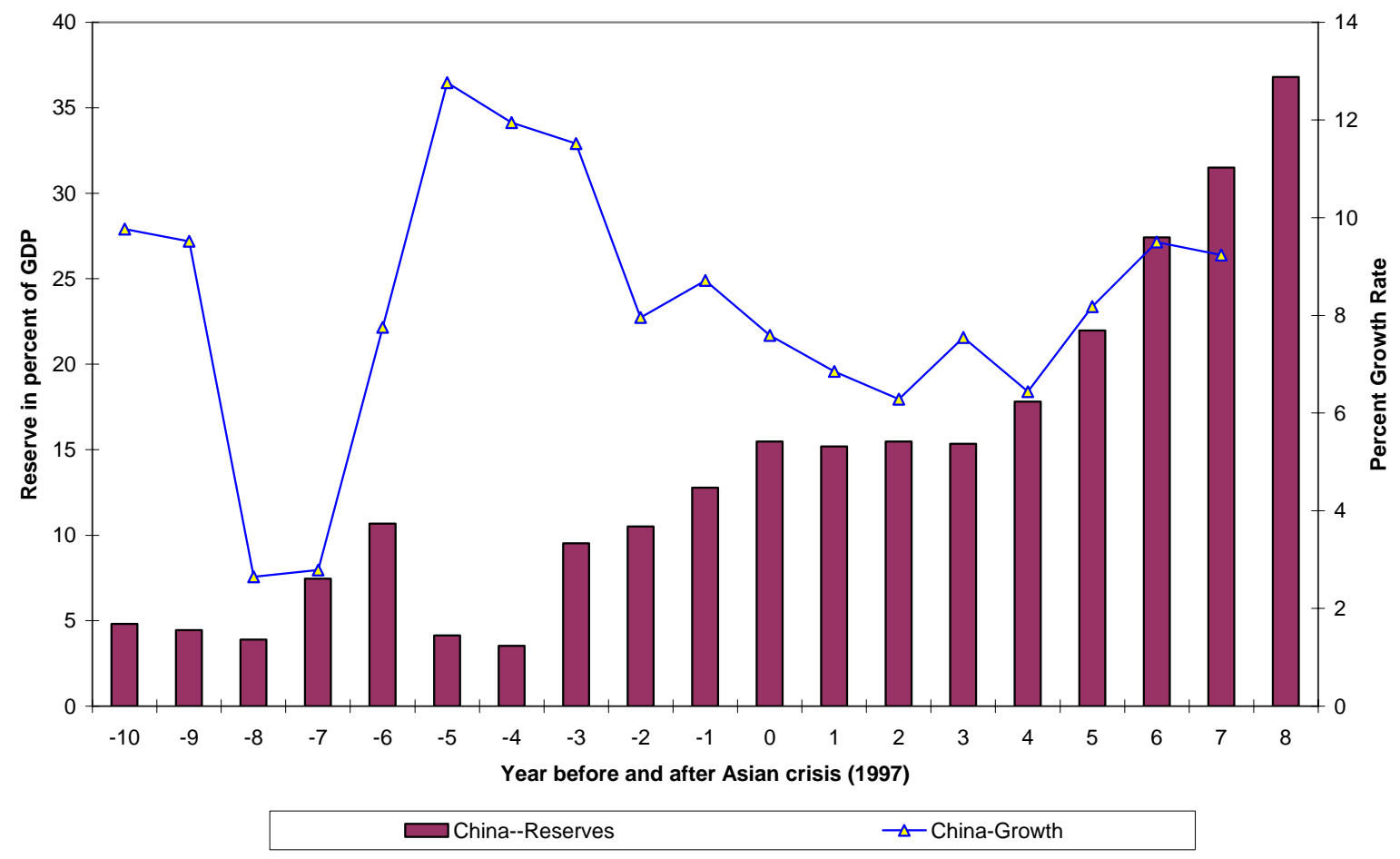




\section{References}

Aizenman, Joshua and Nancy P. Marion, 2003, “The High Demand for International Reserves in the Far East: What's Going On?” Journal of the Japanese and International Economies, Vol. 17, pp. 370-400.

__ 2004, “International Reserves Holdings with Sovereign Risk and Costly Tax Collection,” Economic Journal, Vol. 114, pp. 569-91.

Aizenman, Joshua and Jaewoo Lee, 2005, “International Reserves: Precautionary versus Mercantilist Views, Theory and Evidence," forthcoming, Open Economies Review.

Amsden, Alice H., 1989, “Asia’s Next Giant: South Korea and Late Industrialization,” Oxford University Press.

Barnett, Steven, 2004, “Banking Sector Developments," in China's Growth and Intergration into the World Economy, edited by Eswar Prasad, IMF Occassional Paper No. 232, pp.43-50.

Ben-Bassat Avraham and Daniel Gottlieb, 1992, “Optimal International Reserves and Sovereign Risk,” Journal of International Economics, Vol 33, pp. 345-62.

Bonin P. John and Yiping Huang, 2001, “Dealing with the bad loans of the Chinese banks,” Journal of Asian Economics, 12.2, Summer 2001, pp. 197-214

Caballero, Ricardo and Stavros Panageas, 2004, “A Quantitative Model of Sudden Stops and Liquidity Management,” Manuscript, MIT.

Cabellero, Ricardo, Emmanuel Farhi, and Pierre-Olivier Gourinchas, 2005, “An Equilibrium Model of Global Imbalances and Low Interest Rates,” Manuscript, MIT.

Chang, Roberto and Andres Velasco. 1999. "Liquidity Cerises in Emerging Markets: Theory and Policy," NBER/Macroeconomics Annual, 1999, 11-57.

Cheung, Yin-Wong, Menzie D. Chinn, and Eiji Fujii, 2006, “The Overvaluation of Renminbi Undervaluation,” Manuscript, UCSC.

Cheung, Yin-Wong and XingWang Qian. (2006), "Hoarding of International Reserves: Mrs Machlup’s Wardrobe and the Joneses,” manuscript, UCSC.

Doi Takero and Takeo Hoshi, 2002, “FILP: How Much Has Been Lost? How Much More Will Be Lost?” Manuscript, UCSD.

Dooley P. Michael, David Folkerts-Landau, and Peter Garber. International Financial Stability Deutsche Bank, October, 2005. This is a manuscript with all their papers, at http://econ.ucsc.edu/ mpd/Int\%20Fin\%20Stab.pdf.

Eichengreen, Barry, 2006, “Insurance Underwriter or Financial Development Fund: What Role for Reserve Pooling in Latin America?” NBER Working Paper No. 12451.

Fundenberg D. and J. Tirole, 1983, “Learning by Doing and Market Performance,” Bell Journal of Economics, Vol. 14, pp. 522-30.

Garcia, Pablo, and Claudio Soto, 2004, “Large Holdings of International Reserves: Are They Worth It?” Central Bank of Chile, Working Papers No 299.

Hutchison, M. Michael and Ilan Noy. 2005. "How Bad Are Twins? Output Costs of Currency and Banking Crises" Journal of Money, Credit, and Banking, 37, 4, 725-752.

Imbs, Jean and Paolo Mauro, 2006, “Pooling Countries,” Manuscript, IMF. 
Iwamoto, Yasushi, 2002, “The Fiscal Investment and Loan Program in Transition,” Manuscript, Hitotsubashi University.

Jeanne, Olivier and Romain Ranciere, 2005, “The Optimal Level of International Reserves for Emerging Market Economies: Formulas and Applications,” IMF Research Department.

Kaminsky, Graciela L. and Carmen M. Reinhart. 1999. "The Twin Crises: The Causes of Banking and Balance-ofPayments Problems," American Economic Review; 89(3): 473-500.

Kim, Kihwan and Danny Leipziger, 1993, “Korea: A Case of Government Led Development,” World Bank Country Study, Washington DC.

Krueger, Russell, 2002, "International Standards for Impairment and Provisions and Their Implications for Financial Soundness Indicators (FSIs),” Manuscript, International Monetary Fund.

Krugman, Paul, 1987, "The Narrow Moving Band, the Dutch Disease, and the Competitive Consequences of Mrs. Thatcher: Notes on Trade in the Presence of Dynamic Scale Economies," Journal of Development Economics, Vol. 27, pp. 41-55.

Lardy, Nicholas R., 1998, China's Unfinished Economic Revolution, Washington D.C.

Leahy Dermot and Peter Neary, 1999, “Learning by Doing, Precommitment and Infant-Industry Promotion,” Review of Economic Studies, Vol. 12:3, pp. 435-40.

Lee, Jaewoo, 1996, “Financial Development by Learning,” Journal of Development Economics, Vol. 50, pp. 14764.

— 2004, “Insurance Value of International Reserves,” IMF Working Paper No. 04/175.

McCauley, Robert, 2005, “Distinguishing Global Dollar Reserves from Official Holdings in the United States,” BIS Quarterly Review September 2005, pp. 57-72.

Melitz, Jacques, 1996, “Assessing the Costs of European Monetary Union” Atlantic Economic Journal, Vol. 24, No. 4, pp. 269-80.

Noland, Marcus, 2005, “South Korea’s Experience with International Capital Flows,” NBER WP No. 11381.

Noland, Marcus and Howard Pack, 2002, “Industrial Policy in an Era of Globalization,” Washington: Institute for International Economics.

Rajan, Raghuram and Luigi Zingales, 2003, “Saving Capitalism from Capitalists,” Crown Business.

Rodrik, Dani, 1995, “Getting Interventions Right: How South Korea and Taiwan Grew Rich,” Economic Policy, No. 20.

— 2005, “The Social Cost of Foreign Exchange Reserves,” forthcoming, International Economic Journal. Romer, P., 1990, “Endogenous Technical Change,” Journal of Political Economy, Vol. 98, No. 5, pp. S71-S102. Spencer B. and J. A. Brender, 1983, “International R\&D Rivalry and Industrial Policy,” Review of Economic Studies, Vol. 50, pp. 707-22.

Syropoulos, C., 2002, “Optimum Tariffs and Retaliation Revisited: How Country Size Matters,” The Review of Economic Studies, Vol. 69, No. 3, pp. 707-727.

The World Bank, 1993, “The East Asian Miracle,” Oxford University Press.

Wyplosz, Charles, 2002, “Regional Monetary Arrangements: Lessons from Europe,” Manuscript, Graduate Institute for International Studies. 
Wyplosz, Charles, 1996, “French Postwar Growth:From (Indicative) Planning to (Administered) Market, in N. Crafts and G. Toniolo eds. Economic Growth in Europe since 1945, Cambridge University Press. 